\title{
Analysis of Outpatient's Waiting Time and Patient's Satisfaction at Dr M Djamil Hospital 2019
}

\author{
Adila Kasni Astiena ${ }^{1}$, Fadilla Azmi² \\ \{dr.adilakasni@gmail.com ${ }^{1}$, fadillaazmi@gmail.com ${ }^{2}$ \} \\ Public Health, Andalas University, Padang, Indonesia ${ }^{1,2}$
}

\begin{abstract}
Djamil Hospital is currently in the Type A category which is a national referral hospital. Data 9 of 10 patients waiting to wait more than 60 minutes. The purpose of this study was to determine the waiting time and patient satisfaction at the M. Djamil Hospital Polyclinic in 2019. This study used a qualitative method conducted in March - October 2019. This study was conducted on 10 polyclinic patients who will be interviewed to get information about their experience using Random Block Sampling. Data is collected through interviews, observations, and document review. The average waiting time for patients to receive doctor's services is 2 hours 11 minutes. Associated with a long waiting time makes patients wait dissatisfied. Based on the results of this data it can be concluded that the length of waiting time exceeds the predetermined standard ( $\leq 60$ minutes).
\end{abstract}

Keywords: M Djamil General Hospital Center, Outpatient, Satisfaction, Waiting Time

\section{Introduction}

Hospital is a health service institution that conducts complete individual health services that provide inpatient, outpatient and emergency services. Plenary Health Services are health services that include promotive, preventive, curative, and rehabilitative (Law Number 44/2009). The main function of the hospital is focused on curative and rehabilitative services. In carrying out this function, the hospital has a production unit and a support unit. One of the production units is Outpatient Installation[1].

General Hospital is one of the institutions owned by the regional government that organizes public services, namely health recovery and healing of diseases. In the Minister of Empowerment and State Apparatus Regulation Number 14 of 2017 it is stated that every public service institution is required to conduct a community satisfaction survey [2]

Specifically for hospitals, Community Satisfaction Survey is regulated in Decree of the Minister of Health of the Republic of Indonesia Number 129 of 2008 concerning Hospital Minimum Service Standards that must be fulfilled by every hospital in Indonesia, including M Djamil Hospital. Based on Minimum Service Standards of Hospital, regulates customer satisfaction and service waiting times. Customer Satisfaction related to service quality. Customer satisfaction in Outpatient Installation is regulated in Decree of the Minister of Health of the Republic of Indonesia Number 129 in 2008. Kepmenkes no 129 in 2008 also regulates service waiting time standards at Outpatient $[3,4,5]$.

Hospital waiting times and customer satisfaction need evaluation for improvement.The long waiting time reflects the inadequate management of health services and the impact on the effectiveness and efficiency of services and the lack of patient satisfaction. Satisfied patients 
will visit again, while dissatisfied patients will share their dissatisfaction with others, thereby reducing other people's interest in visiting the hospital [6].

Waiting time and dissatisfaction of patients that are not managed properly can reduce hospital efficiency indicators such as, the lack of a number of visits, the low Bed Occupancy Rate (BOR). M Djamil Hospital is a government-owned hospital located in the city of Padang. in addition, M Djamil Hospital is a teaching hospital. Based on the report on the Hospital Information System it is known that the number of patients served in outpatient installations is $83.5 \%$, this is much higher than the emergency room and inpatient installations [7].

The high number of outpatient visits requires special attention to be evaluated and improvement in each indicator, especially in terms of waiting time and patient satisfaction. Based on the background of the problem, the problem formulation of this study is "What is the waiting time for figure services and patient satisfaction in the Outpatient Installation of M Djamil Hospital Centre?". The purpose of this study was to determine patient waiting time and satisfaction using Permenpan Method number 14 in 2017 and Servqual Method in Outpatient Installation at M Djamil Hospital in 2019.

\section{Methodology}

The design of this study is the mixed method. the quantitative method calculates waiting times and evaluates patient satisfaction with a questionnaire. Patient satisfaction uses hospital environmental indicators, management processes, experience of health care, diagnosis and treatment, and the patient's relationship with the doctor. In the qualitative section, a sample was interviewed regarding the experience of treatment at the M Djamil Hospital. In addition to using interview techniques, researchers also conducted observations and study of documents at M Djamil Hospital Centre. The study was conducted at the Outpatient Installation of M Djamil Hospital Centre which is held in March to November 2019. The population of waiting time and customer satisfaction is outpatients. The sample is part of the number and characteristics possessed by the population, where the sample must be representative so that the conclusions from the sample can be applied to the population $[3,8,9]$. The sampling technique in this study uses a random Block Sampling system which is determined according to the scope of the Outpatient Installation of M Djamil Hospital Centre.

\section{Results}

M Djamil Hospital Centre stands on an area of 8.576 hectares with a building area of 58,079 M2 and has 800 beds. M Djamil Hospital Centre is currently included in the Type A category which is a national referral hospital that has been fully accredited by the Hospital Accreditation Committee.[7]

From the results of the study note that $80 \%$ of respondents are female $(80 \%)$, aged $<58$ years $(60 \%)$, have a high school education and equivalent $(50 \%)$, work in the category of "other" (90\%), and are patients receiving aid Contributions of 50\%. 
Table 1. Waiting Time for Outpatients M Djamil Hospital Centre of 2019

\begin{tabular}{lcc}
\hline \multicolumn{1}{c}{ Waiting Time } & Amount & Prosentase (\%) \\
\hline$\leq 60$ Menit & 1 & 10.0 \\
61 Menit-120 Menit & 4 & 40.0 \\
$\geq 120$ Menit & 5 & 50.0 \\
Amount & 10 & 100.0 \\
\hline
\end{tabular}

Sources : Processed Survey Result, 2019

From the table it can be seen that only $10 \%$ of the sample has a waiting time of $\leq 60$ minutes. The majority of respondents' waiting time $(90 \%)$ is in the category of more than menit 60 minutes. Even 50\% of them waited more than 2 hours.

Based on the results of in-depth interviews, several patients who went to M Djamil Hospital Centre stated that the length of the tuggu time did not become too large, considering that M Djamil Hospital Centre is a referral hospital for the Central Sumatra region. The length of waiting time at the polyclinic is very far from the established standards. There are even patients who wait up to 10 hours to get doctor's services.

Long waiting times don't only occur while waiting for the doctor. At the time of registration requires a long queue, so it requires a long time to wait. Even though the service is carried out by other health workers in the morning, if the new doctor's arrival schedule is around 10:00 a.m, the patient's waiting time becomes long. Discipline of doctors can be improved by providing clear rules from the hospital management and installation head followed by the presence of reward and punishment. Rewards and punishments can be related to non-material materials such as staffing rules and service delivery (remuneration). If the arrival is not on time, there will be restrictions on services. Employees, including doctors or anyone who is not disciplined in the delivery of services will disrupt service performance, resulting in a lack of patient satisfaction that will impact on the intention to re-visit. The lack of patients has an impact on the lack of hospital revenue so that services will be reduced. With this kind of awareness, employees can understand the importance of the disciplinary relationship with the services they receive.

Firmness is required from top management followed by the head of the installation in terms of service discipline, especially with regard to service attendance hours (related to waiting times) and speed of service delivery. The length of time waiting for service has an impact on patient satisfaction, because it takes up time. In addition, not only in terms of time, patients also lose their income, because they have to wait a long time in the hospital. This relates to the average patient working in the informal sector, such as casual laborers, day laborers, traders, farmers and other day laborers.

The length of waiting time at the polyclinic is very far from the established standards. There are even patients who wait up to 10 hours to get doctor's services. As stated by one patient:

"Hmm, the waiting time is very long. To queue takes one day. I came here at 6 in the morning and finished at 4 in the afternoon. But the longest waiting time is the waiting time at registration and the waiting time for the doctor's arrival. That is the longest. I once waited for a doctor for up to 4 hours." (Inf-10, 2019) 
Long waiting times don't only occur while waiting for the doctor. At the time of registration requires a long queue, so it requires a long time to wait. This is as stated by a patient:

"waiting here is very tiring. takes a long time to be treated because the waiting time is quite long, either waiting time in administration or waiting time in the polyclinic itself, even more so now I have to visit two different polyclinics so it requires more time because I have to go back and forth from one place to another place. this feels tiring." (Inf-8, 2019)

Patients satisfaction of the Hospital Environtment can be seen in table 2 below:

Table 2. Hospital Environtment

\begin{tabular}{|c|c|c|c|c|c|c|c|}
\hline \multirow{2}{*}{ No } & \multirow{2}{*}{ Questions } & \multicolumn{5}{|c|}{ Amount (Person) } & \multirow{2}{*}{ Averag } \\
\hline & & STS & TS & BB & $\mathbf{S}$ & SS & \\
\hline & Hos pital Environment & & & & & & \\
\hline 1 & There is a clear direction to the polyclinic & 0 & 0 & 2 & 3 & 5 & 4.3 \\
\hline 2 & $\begin{array}{l}\text { Health workers provide instructions and } \\
\text { explanations }\end{array}$ & 1 & 0 & 0 & 3 & 6 & 4.3 \\
\hline 3 & Clean and comfortable toilet & 0 & 0 & 4 & 2 & 4 & 4.0 \\
\hline 4 & Non smoking waiting room & 0 & 0 & 0 & 1 & 9 & 4.9 \\
\hline 5 & The waiting room is clean and feels comfortable & 0 & 0 & 1 & 4 & 5 & 4.4 \\
\hline 6 & There are enough seats in the waiting room & 0 & 6 & 0 & 2 & 2 & 3.0 \\
\hline 7 & $\begin{array}{l}\text { Facilities such as reading material / magazines } \\
\text { and other information media are available in the } \\
\text { patient waiting room }\end{array}$ & 0 & 5 & 1 & 2 & 2 & 3.1 \\
\hline 8 & $\begin{array}{l}\text { There are entertainment facilities such as } \\
\text { television or wifi in the lounge }\end{array}$ & 1 & 5 & 0 & 3 & 1 & 2.8 \\
\hline
\end{tabular}

Source : Questionnaire Data Processing, 2019

Note :

STS : Strongly disagree

TS : Disagree

BB : Normal

$\mathrm{S}$ : Agree

SS : Strongly agree

Based on table 2, it can be seen that from the 8 available indicators, only the indicator "smoke-free waiting room" of which respondents "strongly agree" with the statement. For other indicators, only 6 of respondents stated the highest "strongly agree". Even for the indicator "provided enough seats in the waiting room", 6 of respondents said "disagree" with the statement.

Lack of seats provided by M Djamil Hospital Centre makes many patients wait while standing, this will certainly affect the comfort of patients in treatment. Besides that, the length of waiting time needed to meet the doctor, because administrative matters make the patient feel bored, so that entertainment media is needed so that patients do not feel bored in waiting. This is also consistent with the results of interviews with several patients / visitors: 
"the place is nice but narrow. very crowded, lots of people waiting were standing because the seats were lacking, the place was also hot maybe because it was crowded, the reading room was not there but the tv was there but the sound was not heard, in my opinion there was no need for wifi because I also didn't really need it." (Inf-4, 2019)

"I'm bored waiting. spend one day for treatment. but it must be done. there should be a TV, as a medium of entertainment while waiting, so that it can eliminate boredom." (Inf-7, 2019)

Patients satisfaction of the Hospital environment can be seen in the following table 3 :

Table 3. Management Process

\begin{tabular}{|c|c|c|c|c|c|c|c|}
\hline \multirow{2}{*}{ No } & \multirow{2}{*}{ Questions } & \multicolumn{5}{|c|}{ Amount (Person) } & \multirow{2}{*}{ Average } \\
\hline & & STS & TS & BB & $\mathbf{S}$ & SS & \\
\hline & Management Process & & & & & & \\
\hline 9 & $\begin{array}{l}\text { The length of waiting time in the administration } \\
\text { section is acceptable }\end{array}$ & 1 & 5 & 2 & 2 & 0 & 2.5 \\
\hline 10 & $\begin{array}{l}\text { The waiting time at the clinic before consulting a } \\
\text { doctor is acceptable }\end{array}$ & 0 & 4 & 2 & 4 & 0 & 3.0 \\
\hline 11 & $\begin{array}{l}\text { There is enough time for a consultation with a } \\
\text { doctor to be accepted }\end{array}$ & 0 & 0 & 1 & 6 & 3 & 4.2 \\
\hline 12 & Waiting times for laboratory tests are acceptable & 1 & 2 & 1 & 3 & 2 & 3.0 \\
\hline 13 & $\begin{array}{l}\text { Waiting times for pharmacy services can be } \\
\text { accepted }\end{array}$ & 1 & 1 & 2 & 4 & 0 & 2.5 \\
\hline 14 & $\begin{array}{l}\text { The waiting time for the billing process can be } \\
\text { accepted }\end{array}$ & 0 & 0 & 0 & 5 & 2 & 3.0 \\
\hline & Rerata & 0.2 & 1.6 & 1.0 & 3.5 & 3.4 & 3.74 \\
\hline \multicolumn{8}{|c|}{$\begin{array}{l}\text { Source : Questionnaire Data Processing, } 2019 \\
\text { Note : }\end{array}$} \\
\hline STS & : Strongly disagree & & & & & & \\
\hline TS & : Dis agree & & & & & & \\
\hline $\mathrm{BB}$ & : Normal & & & & & & \\
\hline $\mathrm{S}$ & : Agree & & & & & & \\
\hline SS & : Strongly agree & & & & & & \\
\hline
\end{tabular}

Based on table 3, it can be seen that from the 6 indicators in the management process, only 3 indicators were given a rating of "strongly agree" by the respondent, 2 of respondents stated "strongly agree" with the statement "labor inspection waiting time is acceptable" and "when the billing process can be accepted "and 3 of respondents stated" strongly agree "to the statement" there is enough time for consultation with a doctor ". While for the indicator "the length of waiting time in the administration is acceptable", 5 of respondents said "disagree" with the statement. Even for the indicators "pharmacy waiting time is acceptable", "labor inspection waiting time is acceptable" and "administration waiting time is acceptable, 1 of respondents each said" strongly disagree "with the statement. 
Patients satisfaction of the hospital environment can be seen in the following table 4:

Table 4. Health Services Experience

\begin{tabular}{|c|c|c|c|c|c|c|c|}
\hline \multirow{2}{*}{ No } & \multirow{2}{*}{ Questions } & \multicolumn{5}{|c|}{ Amount (Person) } & \multirow{2}{*}{ Average } \\
\hline & & STS & TS & BB & $\mathbf{S}$ & SS & \\
\hline & Health Services Experience & & & & & & \\
\hline 15 & $\begin{array}{l}\text { It feels comfortable to get a queue number before } \\
\text { registration }\end{array}$ & 0 & 0 & 2 & 4 & 4 & 4.2 \\
\hline 16 & $\begin{array}{l}\text { There is an online registration application to } \\
\text { register }\end{array}$ & 0 & 2 & 0 & 4 & 4 & 4.0 \\
\hline 17 & $\begin{array}{l}\text { This online registration application at the } \\
\text { hospital helps reduce waiting times }\end{array}$ & 0 & 3 & 1 & 4 & 2 & 3.5 \\
\hline \multicolumn{8}{|c|}{$\begin{array}{l}\text { Source : Questionnaire Data Processing, } 2019 \\
\text { Note : }\end{array}$} \\
\hline STS & : Strongly disagree & & & & & & \\
\hline TS & : Disagree & & & & & & \\
\hline $\mathrm{BB}$ & : Normal & & & & & & \\
\hline $\mathrm{S}$ & : Agree & & & & & & \\
\hline SS & : Strongly agree & & & & & & \\
\hline
\end{tabular}

Based on table 4 , of the 3 indicators regarding the experience of health services 4 of respondents stated "agree" for each indicator.

Patients satisfaction of the hospital environment can be seen in the following table 5:

Table 5. Diagnosis and Medicine

\begin{tabular}{|c|c|c|c|c|c|c|c|}
\hline \multirow{2}{*}{ No } & \multirow{2}{*}{ Questions } & \multicolumn{5}{|c|}{ Amount (Pers on) } & \multirow{2}{*}{ Average } \\
\hline & & STS & TS & BB & $\mathbf{S}$ & SS & \\
\hline & Diagnosis and Medicine & & & & & & \\
\hline 18 & $\begin{array}{l}\text { Medical staff ask patiently about the } \\
\text { development of the disease }\end{array}$ & 0 & 1 & 0 & 3 & 6 & 4.4 \\
\hline 19 & $\begin{array}{l}\text { Doctors diagnose and explain the treatment plan } \\
\text { patiently }\end{array}$ & 0 & 0 & 0 & 4 & 6 & 4.6 \\
\hline 20 & I feel valued by the medical staff & 0 & 0 & 0 & 4 & 6 & 4.6 \\
\hline 21 & I feel protected by my privacy rights & 0 & 0 & 0 & 4 & 6 & 4.6 \\
\hline $\begin{array}{l}\text { Sourc } \\
\text { Note : }\end{array}$ & : Questionnaire Data Processing, 2019 & & & & & & \\
\hline STS & : Strongly disagree & & & & & & \\
\hline TS & : Disagree & & & & & & \\
\hline $\mathrm{BB}$ & : Normal & & & & & & \\
\hline S & : Agree & & & & & & \\
\hline SS & : Strongly agree & & & & & & \\
\hline
\end{tabular}


Based on the table known from the 4 indicators of satisfaction with diagnosis and medication, each indicator gets a value of "strongly agree" by 6 of respondents stated "strongly agree" for each indicator.

Patients satisfaction of the Hospital environment can be seen in the following table 6 :

Table 6. Patient Relationship with doctors

\begin{tabular}{|c|c|c|c|c|c|c|c|}
\hline \multirow{2}{*}{ No } & \multirow{2}{*}{ Questions } & \multicolumn{5}{|c|}{ Amount (Person) } & \multirow{2}{*}{ Average } \\
\hline & & STS & TS & BB & $\mathbf{S}$ & SS & \\
\hline \multirow[b]{2}{*}{22} & Patient Relations hip with Doctors & & & & & & \\
\hline & $\begin{array}{l}\text { The availability of clear and reliable mechanisms } \\
\text { and means to express opinions and complaints at } \\
\text { this hospital }\end{array}$ & 0 & 2 & 2 & 4 & 2 & 3.6 \\
\hline 23 & Most medical staff can be trusted & 0 & 1 & 1 & 5 & 2 & 3.5 \\
\hline \multicolumn{8}{|c|}{$\begin{array}{l}\text { Source : Questionnaire Data Processing, } 2019 \\
\text { Note : }\end{array}$} \\
\hline STS & : Strongly disagree & & & & & & \\
\hline TS & : Disagree & & & & & & \\
\hline $\mathrm{BB}$ & : Normal & & & & & & \\
\hline S & : Agree & & & & & & \\
\hline SS & : Strongly agree & & & & & & \\
\hline
\end{tabular}

Based on the table, it is known from 2 indicators of satisfaction with the relationship between patient and doctor 4 of respondents "agree" with the statement "the availability of mechanisms and means that are clear and reliable to express opinions and complaints at this hospital", as well as for indicators "most medical staff can be trusted ", 5 of respondents agreed".

\section{Discussion}

The results of the study showed that the waiting time at the M Djamil Hospital Centre Installation exceeds the standard time for service provision stipulated in Kepmenkes number 129 of 2008 where waiting outpatient services $\leq 60$ minutes, meaning that it should not be more than 1 hour. This time is counted from the patient starting to register until served by a specialist. While the results of the survey found that waiting time for inpatients ranged more than 60 minutes (90\%), even $40 \%$ of them received services after waiting more than 2 hours. Not only in M Djamil Hospital Centre, long waiting times are also a major problem in almost all hospitals, including RST Reksodiwiryo and Rasidin District Hospital. Based on the report of the quality of outpatient installations in 2016 showed there are two indicators that are far from the target patient satisfaction. The value of the waiting time indicator for outpatient installations Target of RSUP Dr. M. Djamil which is equal to $\leq 45$ minutes, but at The implementation time reached 94.99 minutes, so Waiting time is only $47.37 \%$ of the target. Second indicator which is still far from the target is patient satisfaction. Target patient satisfaction that is want to succeed outpatient installation is at $90 \%$ but successful only $52.03 \%$. [6,7,10] 
The average waiting time in the 3 hospitals studied is still far from the Hospital Minimum Service Standards. This needs to be a top priority for the hospital to be improved by paying attention to matters related to patient waiting times such as doctor's arrival schedule to the Outpatient Installation, service opening hours and employee discipline in carrying out their duties.[6]

Even though the service is carried out by other health workers in the morning, if the new doctor's arrival schedule is around 10:00 a.m, patient's waiting time becomes long. Discipline of doctors can be improved by providing clear rules from the hospital management and installation head followed by the presence of reward and punishment. Rewards and punishments can be related to non-material materials such as staffing rules and service delivery (remuneration). If the arrival is not on time, there will be restrictions on services. Employees, including doctors or anyone who is not disciplined in the delivery of services will disrupt service performance, resulting in a lack of patient satisfaction that will impact on the intention to re-visit. The lack of patients has an impact on the lack of hospital revenue so that services will be reduced. With this kind of awareness, employees can understand the importance of the disciplinary relationship with the services they receive.

Firmness is required from top management followed by the head of the installation in terms of service discipline, especially with regard to service attendance hours (related to waiting times) and speed of service delivery. The length of time waiting for service has an impact on patient satisfaction, because it takes up time. In addition, not only in terms of time, patients also lose their income, because they have to wait a long time in the hospital. This relates to the average patient working in the informal sector, such as casual laborers, day laborers, traders, farmers and other day laborers.

Patient satisfaction is one important indicator in an effort to improve the quality of service. If the patient feels satisfied then the patient will feel comfortable and have the will to visit again if needed. Even if the patient is satisfied with the services provided by the hospital, it is also possible that the patient will tell about his experience and promote the hospital to his relatives and relatives. But satisfaction is sometimes difficult to obtain, especially for public servants. The complexity of the problems at the hospital makes patients feel uncomfortable. Starting from the lack of seating facilities that do not match the number of patient visits, many patients are standing waiting for the queue for registration. The long waiting time also triggers problems in public services, especially hospitals. Long waiting time will affect patient satisfaction, so sometimes patients prefer not to seek treatment, because it is very time consuming and loss of income for daily workers. Another indicator that influences patient satisfaction is the behavior and attitude of officers in providing services. Due to the large number of patients served in a day, it sometimes makes the staff seem less friendly, but it must be a concern for management to always remind and motivate staff to always apply service in providing services.[6]

\section{Conclusions}

The result in an average patient waiting time from getting a queue to ask the doctor for queuing time is 2 hours 11 minutes. $90 \%$ of respondents get healthcare after waiting more than 1 hour. The problem was caused by the length of time the doctor arrived, the long status found in the medical records unit, as well as the initial registration process which was caused by a high visit rate. Related to the long waiting time makes the patient feel dissatisfied. Based on the results of these data it can be concluded that the length of waiting time exceeds a predetermined standard ( $\leq 60$ minutes). One solution to the long waiting time is to add an initial registration counter. 


\section{Reference}

[1] Aditama, TY., 2007, Manajemen Administrasi Rumah Sakit, Universitas Indonesia Press, Jakarta.

[2] Menteri Pemberdayaan dan Aparatur Negara, 2017, SK Nomor : Kep/14/M.PAN/2/2017 tentang Pedoman Umum Penyusunan Indeks Kepuasan Masyarakat Unit Pelayanan Publik.

[3] Astiena AK., 2015. Manajemen Sumber Daya Manusia Kesehatan. Unand Press : Padang.

[4] Astiena AK, Syah NA. The Analysis of Patiens Satisfaction of Some Public Health Centres in Padang. Annals of Tropical Medicines and Public Health. Year 2017. Volume 10 Issue 1 Page 109-116

[5] Menteri Kesehatan Republik Indonesia, 2008, SK Nomor :129/Menkes/SK/II/2008 tentang Standar Pelayanan Minimal Rumah Sakit.

[6] Astiena, AK, Lipoeto NI. Laporan Survey Kepuasan RSUD Rasidin 2018

[7] Ikhsan,W. 2016. Minimasi Waktu Penyediaan Status Rekam Medis pada Instalasi Rekam Medis RSUP dr. M. Djamil. Padang: Universitas Andalas.

[8] Sugiyono, 2008, Metode Penelitian Administrasi, Alfabeta, Bandung

[9] Wijono, Djoko. 2008. Manajemen Mutu Rumah Sakit dan Kepuasan Pasien. Duta Prima Airlangga. Surabaya.

[10]Dinas Kesehatan Propinsi Sumatera Barat, Program Pascasarjana S2 Kesehatan Masyarakat Fakultas Kedokteran Universitas Andalas, 2012. Laporan Survey Kepuasan Peserta Jamkesda Terhadap Pelayanan Kesehatan di Rumah Sakit Pemerintah Propinsi Sumatera Barat. Padang. 